\title{
Sciendo
}

Acta Veterinaria-Beograd 2021, 71 (1), 131-136

Case report

UDK: 636.182.09:617.77-006.327

636.182.09:[616.98:578.827

DOI: $10.2478 /$ acve-2021-0011

\section{SARCOID IN THE LOWER EYELID DUE TO BOVINE PAPILLOMAVIRUS-2 IN A DONKEY (EQUUS ASINUS)}

\author{
EROKSUZ Yesari ${ }^{1 *}$, ABAYLI Hasan², CANPOLAT Ibrahim³, \\ AKDENIZ INCILI Canan ${ }^{1}$, KARABULUT Burak ${ }^{1}$, TANRISEVER Murat ${ }^{3}$, \\ BEYTUT Enver ${ }^{4}$
}

${ }^{1}$ Department of Pathology, Faculty of Veterinary Medicine, Firat University, Elazig - TURKEY;
${ }^{2}$ Department of Virology, Faculty of Veterinary Medicine, Firat University, Elazig - TURKEY;
${ }^{3}$ Department of Surgery, Faculty of Veterinary Medicine, Firat University, Elazig - TURKEY;
${ }^{4}$ Department of Pathology, Faculty of Veterinary Medicine, Kafkas University, Kars- TURKEY

(Received 16 December 2020, Accepted 02 February 2021)

\begin{abstract}
Sarcoid tumors were described by means of histopathological and molecular procedures in a 5-year-old donkey. Histopathological examination showed epithelial changes including hyperkeratosis, epithelial hyperplasia, koilocytosis, and rete peg formation. Neoplastic fibroblastic cells were plumb, large spindle to stellate and embedded in dense collagenous tissue. Results of Polymerase Chain Reaction and DNA sequence analysis showed that the etiological agent belonged to Bovine Papilloma Virus-II species in the delta papilloma virus genus. This case study represents the first report demonstrating the presence of Bovine Papilloma Virus-II in donkey sarcoid.
\end{abstract}

Key words: Bovine papillomavirus-2, donkey, Equus asinus, sarcoid,

\section{INTRODUCTION}

Papillomaviridae are non-encapsulated oncogenic viruses with circular, double-stranded DNA, infecting the epithelium. Most of the papillomaviruses are highly host specific, however, bovine papilloma virus (BPV) has cosmopolitan features infecting both bovine and equine species [1]. These viruses are classified in 5 genera including Deltapapillomavirus, Xipapillomavirus, Epsilonpapillomavirus, Dyoxipapillomavirus and Dyokappapapillomavirus. Other new BPVs (18, 19 and 21) are not included in any genus [2]. The classification is based on genomic DNA homology, particularly the highly conserved L1 gene encoding a structural protein [3].

BPV-1, 2 and 13 are responsible for the occurrence of sarcoid tumors in equids [4]. These tumors are locally aggressive, fibroblastic benign proliferations, which are the most common skin tumors in horses. They are often present at sites of previous

*Corresponding author: e-mail: yeroksuz@firat.edu.tr 
trauma or scarring with typical clinical appearance. However, the diagnosis is based on histopathological and molecular analysis. Their prevalence ranges from 1\% to $12 \%$ in horses $[4,5]$. Most of the studies on sarcoid tumors are focused on horses, however limited numbers of studies are available in other equids [5]. Despite some studies in equine sarcoid and bovine papilloma virus exist in Turkey [6,7], to the authors' knowledge, no report on sarcoid in donkeys is available.

The aim of this report is to describe the clinical, pathological and molecular findings of equine sarcoma on the skin of the lower eyelid in a 5-year-old donkey.

\section{CASE REPORT}

A five-year-old donkey was referred to the Hospital of Veterinary Medical School of Firat University. Grossly, the right lower eyelid was thickened by the mass (Fig1A) which was surgically resected. The tumor also caused keratitis characterized by vascularization, edema and scar formation. Topical ophthalmic pomade (Polymixine B Sulfate, Oxytetracycline $\mathrm{Hcl}$ and Terramycin) was used for keratitis. The cut surfaces of the tumor had a lobular appearance and hard in consistency. The dimension was

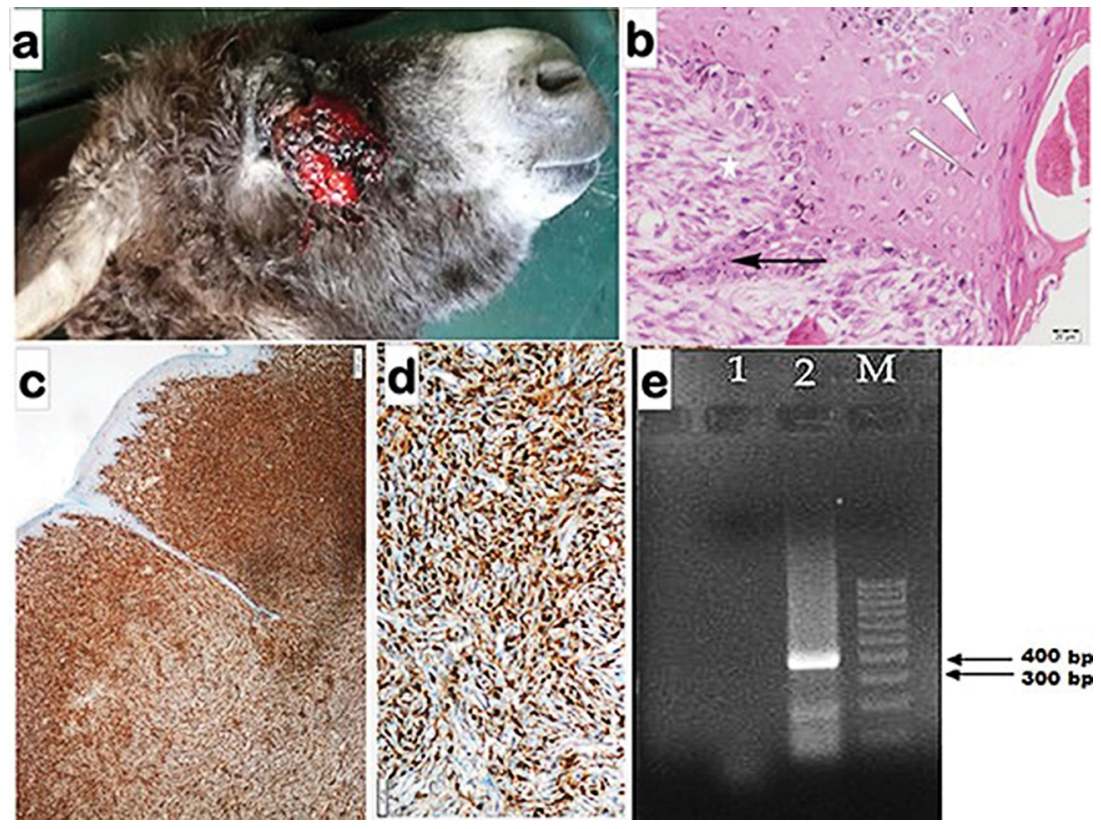

Figure 1. a. Well circumsized mass having granular surface on the lower eyelid; b. Rete ridge formation (arrow), koilocytosis (arrow heads) and perpendicularly oriented fibroblasts (star) at the dermal-epidermal connection; $\mathbf{c}$. Diffuse and strong immune reaction characterized by granular cytoplasmic staining to vimentin in the dermis; $\mathbf{d}$. Diffuse and strong immunoreaction characterized by cytoplasmic staining to S-100 in the dermis; e. 2\% Agarose gel electrophoresis of PCR products amplified with semi-nested PCR from the clinical sample taken in eyelid. M; 100 bp DNA ladder (Sigma, USA).

Lane 1: negative control $\left(\mathrm{dH}_{2 \mathrm{O}}\right)$, Lane 2: semi-nested PCR of the clinical sample; $386 \mathrm{bp}$. 
$4 \times 5 \times 3 \mathrm{~cm}$ and weighed 140 grams. Recurrence occurred 6 months after surgery and euthanasia was performed upon the owner's request.

Tissue samples were fixed in 10\% formalin solution. Paraffin blocks prepared by routine methods were cut approximately $5 \mu \mathrm{m}$ in thickness and stained with hematoxylineosin method (H\&E).

Immunohistochemistry analysis for vimentin and S-100 was performed using autostainer (Ventana Benchmark Ultra), whereas immunohistochemistry for BPV was manually performed. Details of primary antibodies used for immunohistochemical analysis are given in Table-1. During all staining steps, the sections were washed in PBS (Phosphate Buffered Saline, pH 7.6). For immunolabeling 3,3', diaminobenzidine (DAB) and Mayer's hematoxylin were used as the chromogen and the counterstain, respectively.

Table 1. Details of primary antibodies used for immunohistochemical analysis.

\begin{tabular}{llccc}
\hline $\begin{array}{l}\text { Primary } \\
\text { antibodies }\end{array}$ & Pretreatment & $\begin{array}{c}\text { Primary } \\
\text { antibody } \\
\text { dilution }\end{array}$ & $\begin{array}{c}\text { Incubation } \\
\text { conditions }\end{array}$ & $\begin{array}{c}\text { Commercial reference } \\
\text { and } \\
\text { clone no. }\end{array}$ \\
\hline $\begin{array}{l}\text { Polyclonal rabbit } \\
\text { anti-BPV }\end{array}$ & Microwave oven & $\begin{array}{c}\text { Prediluted, } \\
\text { ready to use }\end{array}$ & $\begin{array}{c}\text { Room } \\
\text { temperature }\end{array}$ & $\begin{array}{c}\text { Dako } \\
\text { (Catalog no. N1547) }\end{array}$ \\
$\begin{array}{l}\text { Rabbit polyclonal } \\
\text { antibody to }\end{array}$ & Microwave oven & $\begin{array}{c}\text { Prediluted, } \\
\text { ready to use }\end{array}$ & $\begin{array}{c}\text { Room } \\
\text { temperature }\end{array}$ & $\begin{array}{c}\text { Novocastra } \\
\text { (Code: NCL-L- S100p) }\end{array}$ \\
$\begin{array}{l}\text { R-100 protein } \\
\text { Rabit monoclonal } \\
\text { Vimentin }\end{array}$ & Microwave oven & $\begin{array}{c}\text { Prediluted, } \\
\text { ready to use }\end{array}$ & $\begin{array}{c}\text { Room } \\
\text { temperature }\end{array}$ & $\begin{array}{c}\text { Thermo } \\
\text { (Code: MA5-11883) }\end{array}$ \\
\hline
\end{tabular}

Serial sections in $4 \mu \mathrm{m}$ thickness were deparaffinized in xylene and rehydrated through graded alcohol. The sections were placed in citrate buffer saline ( $\mathrm{pH}$ 6.0) in a microwave oven for $20 \mathrm{~min}$ for antigen retrieval. Endogenous peroxidase activity was blocked with $5.0 \% \mathrm{H}_{2} \mathrm{O}_{2}$ in methanol for $10 \mathrm{~min}$. Primary antibodies were omitted from negative control sections, whereas, for the positive control, bovine viral papilloma samples were used from the archive.

Genomic DNA was extracted from the mass using a commercial extraction kit (Wizard Genomic DNA Extraction System) as recommended by the manufacturer (Promega Corp., Madison, WI). The DNA pellets were dissolved in $50 \mu \mathrm{l}$ distilled water and were stored at $-20{ }^{\circ} \mathrm{C}$ pending analysis.

Semi-nested PCR method for BPV-2 was used as previously described [8]. PCR reaction was carried out in a total of $50 \mu \mathrm{l}$ PCR mixture including $5 \mu$ l of template DNA, $5 \mu \mathrm{l} 10$ x PCR Buffer (670mM Tris-HCl, pH 8,8, 0.1\% Tween-20, 160mM $\left(\mathrm{NH}_{4}\right)_{2} \mathrm{SO}_{4}, 25 \mathrm{mM}$ Magnesium chloride), $2 \mathrm{mM}$ from each of the 4 deoxynucleotides, 1U Taq DNA polymerase (Bioron), $0.2 \mathrm{M}$ primers [BPVP1 (5'- TGT TCC CAA AGT 
TGC TG-3') and BPVP2 (5'- CAT TTT GAG GTA GTC TGG-3')]. Amplifications were carried out in two rounds. First stage PCR was performed with the following cycling profile: an initial step of $2 \mathrm{~min}$ at $95^{\circ} \mathrm{C}$, followed by 40 cycles of $1 \mathrm{~min} / 94^{\circ} \mathrm{C}$, $1 \mathrm{~min} / 55^{\circ} \mathrm{C}, 1 \mathrm{~min} / 72{ }^{\circ} \mathrm{C}$, and a final extension step of $5 \mathrm{~min} / 72{ }^{\circ} \mathrm{C}$. The second stage PCR was carried out with BPVP-1 and BPVP-3 (5' - ATT CTA AAG GAG GAC ACG -3) primers and $1 \mu \mathrm{l}$ PCR product taken from the first stage PCR under the same conditions.

Genomic DNA was also used in the PCR step for diagnosis of BPV-1 [9] and BPV13 [10]. PCR products were analyzed by electrophoresis in $2.0 \%$ agarose gel stained with ethidium bromide $(0.5 \mu \mathrm{g} / \mathrm{ml})$ and visualized under UV light. Sequence analysis of amplification detected at the expected size after electrophoresis was performed at Macrogen laboratory. The obtained sequence data were verified by testing with BLASTN (http://www.ncbi.nlm.nih.gov) and stored in the GenBank database: MW053068 (strain name: EquineSarcoids/Asinus/TUR-2018).

The mass was well-circumscribed, not encapsulated and consisted of a variable infiltrative proliferation of fibroblastic cells which were plumb, large spindle to stellate. The nuclei had granular chromatin with prominent nucleoli. Neoplastic cells embedded in dense collagenous tissue. Epithelial changes were hyperkeratosis, epithelial hyperplasia, koilocytosis, and rete peg formation (Fig-C). At the dermalepidermal conjunction, there were fibroblasts oriented perpendicularly to the basement membrane in the so-called "picket fence" arrangement (Fig-c). The number of mitoses was low (1 in high-dry power field).

All the sections of the tumor showed negative immunoreaction to BPV antibodies. However, in the positive control samples (bovine papilloma samples), strong and diffuse nuclear immunoractivity was present in the stratum granulosum and stratum corneum.

As a result of the semi-nested PCR performed with BPVP1- BPVP-3 primers a 386 base pair (bp) specific band was detected in 2\% agarose gel (Fig d). The PCR analysis performed with BPV-I and BPV-XIII specific primers did not result in any amplification. BlastN analysis showed that the EquineSarcoids/Asinus/TUR-2018 strain partial L1 gene shares $98.94 \%$ nucleotide (nt) identity with the TR-B27-BPV2 L1 strain (KY781814.1; coverage of 100\%) from Turkey and Aks-01 strain from China (KM455051.1; coverage of 100\%) and 98.67\% nt identity with BPV2_BR/02AC12 strain from Brazil (MH187961.1; coverage of 100\%). These results showed that the papillomavirus strain obtained from the donkey is in the deltapapillomavirus genus and is highly identical with Bovine Papillomavirus-2 species.

BPV-1, BPV-2 and BPV-13 are the etiologic agents of equine sarcoid tumors. Infection of equids by a bovine virus is a rare example of interspecies transmission for the papilloma virus. Delta-PVs transform mesenchymal cells to tumor cells via BPV E5 oncoprotein by binding and activating platelet-derived growth factor $\mathrm{b}$ receptor 
(PDGF b-r) and increased expression of the phosphoinositide 3-kinase-AKT-cyclin D3 pathway and c-Jun N-terminal kinase [11,12].

It might be challenging to differentiate the equine sarcoid from soft tissue sarcomas especially if the epidermal component had been lost through ulceration, [7]. However, S100 is helpful and is expressed in sarcoids [13], but rarely expressed in equine soft tissue sarcomas.

In a previous study, BPV-1 was reported in a donkey sarcoid [14]. In other surveys $[15,16]$, BPV was reported in donkeys without strain information.

In conclusion; this is the first report of the equine sarcoid caused by BPV-2 in a donkey. Positive immunoreactivity to BPV could not be detected, most probably due to the abortive nature of the infection.

\section{Authors' contributions}

BK and CAI carried out histopathological examinations. MT carried out the surgical process. HA carried out the molecular virological studies. EB carried out immunohistochemistry. YE and IC carried out the draft the manuscript. All authors read and approved the final manuscript.

\section{Declaration of conflicting interests}

The author(s) declared no potential conflicts of interest with respect to the research, authorship, and/or publication of this article.

\section{REFERENCES}

1. Munday JS, Kiupel M: Papillomavirus-Associated Cutaneous Neoplasia in Mammals. Vet Pathol 2010, 47(2):254-264.

2. Munday JS: Bovine and Human Papillomaviruses: A Comparative Review. Vet Pathol 2014, 51(6): 1063-1075.

3. Bernard HU, Burk RD, Chen Z, Van Doorslaer K, Zur Hausen H, De Villiers EM: Classification of papillomaviruses (PVs) based on 189 PV types and proposal of taxonomic amendments. Virology 2010, 401:70-79.

4. Otten N, Tscharner C, Lazary S, Antczak DF, Gerber H: DNA of bovine papillomavirus type 1 and 2 in equine sarcoids: PCR detection and direct sequencing. Arch Virol 1993, 132:121-131.

5. Martens A, De Moor A, Demeulemeester J, Ducatelle R: Histopathological characteristics of five clinical types of equine sarcoid. Res Vet Sci 2000, 69:295-300.

6. Dagalp SB, Dogan F, Farzani TA, Salar S, Bastan A: The genetic diversity of bovine papillomaviruses (BPV) from different papillomatosis cases in dairy cows in Turkey. Arch Virol 2017, 162:1507-1518. 
7. Kanat O, Ataseven VS, Babaeski S, Derelli F, Kumas C, Dogan F, Dagalp SB: Equine and bovine papillomaviruses from Turkish brood horses: a molecular identification and immunohistochemical study. Vet Arh 2019, 89(5):601-611.

8. Wosiacki SR, Barreiro MAB, Alfieri AF, Alfieri AA: Semi-nested PCR for detection and typing of bovine Papillomavirus type 2 in urinary bladder and whole blood from cattle with enzootic haematuria. J Virol Methods 2005, 126:215-219.

9. Lindsey CL, Almeida ME, Vicari CF, Carvalho C, Yaguiu A, Freitas AC, Beçak W, Stocco RC: Bovine papillomavirus DNA in milk, blood, urine, semen, and spermatozoa of bovine papillomavirus-infected animals. Genet Mol Res 2009, 8 (1):310-318.

10. Lunardi M, De Alcântara BK, Otonel RAA, Rodrigues WB, Alfieri AF, Alfieri AA: Bovine papillomavirus type 13 DNA in equine sarcoids. J. Clin. Microbiol 2013, 51(21):67-71.

11. Borzacchiello G, Mogavero S, De Vita G, Roperto S, Della Salda L, Roperto F: Activated platelet derived growth factor b receptor expression, PI3K-AKT pathway molecular analysis and transforming signals in equine sarcoids. Vet Pathol 2009, 46:589-597.

12. Borzacchiello G, Russo V, Della Salda L, Roperto S, Roperto F: Expression of plateletderived growth factor-beta receptor and bovine papillomavirus E5 and E7 oncoproteins in equine sarcoid. J Comp Pathol, 2008, 139:231-237.

13. Epperson ED, Castleman WL. Bovine Papillomavirus DNA and S100 Profiles in Sarcoids and Other Cutaneous Spindle Cell Tumors in Horses. Veterinary Pathology. 2017;54 (1):4452.

14. Nasir L, McFarlane ST, Torrontegui BO, Reid SW: Screening for bovine papillomavirus in peripheral blood cells of donkeys with and without sarcoids. Res Vet Sci 1997, 63(3):289290.

15. Koch C, Ramsauer AS, Drögemüller M, Ackermann M, Gerber V, Tobler K: Genomic comparison of bovine papillomavirus 1 isolates from bovine, equine and asinine lesional tissue samples. Virus Res 2018, 15;244:6-12.

16. Chambers G, Ellsmore VA, O’Brien PM, Reid SWJ, Love S, Campo MS, Nasir L: Association of bovine papillomavirus with the equine sarcoid. J Gen Virol 2003, 84:1055-1062.

\title{
SARKOID DONJEG OČNOG KAPKA KOD MAGARCA (EQUUS ASINUS) IZAZVAN BOVINIM PAPILOMA 2 VIRUSOM
}

\author{
EROKSUZ Yesari, ABAYLI Hasan, CANPOLAT Ibrahim, AKDENIZ INCILI \\ Canan, KARABULUT Burak, TANRISEVER Murat, BEYTUT Enver
}

Sarkoidi su opisani primenom histopatoloških i molelularanih metoda i procedura kod magarca, starog pet godina. Histopatološko ispitivanje, ukazalo je na promene u epitelu koje su uključivale hiperkeratozu, hiperplaziju epitela, koilocitozu i formiranje invaginacija epitela ptema dubokom dermisu - rete peg. Fibroblastine neoplastične ćelije su bile krupne, ovalnovretenaste i zvezdaste, uronjene u tkivo bogato kolagenom. Ispitivanje PCR metodom kao i rezultati DNK sekvencioniranja pokazali su da je etiološki agens spadao u grupu bovinog papilomavirusa-2 koji pripada rodu delta papilomavirusa. Ova studija predstavlja prvi opisani slučaj prisustva papiloma virusa goveda-2 kod sarkoida magarca. 